\title{
Comparative Phytochemical, Antioxidant and Antimicrobial Properties of Ficus capensis, Aristolochia ringens, Albizia zygia and Lannea welwitschii
}

\author{
Wilfred O. Obonga, Philip F. Uzor, Emmanuel O. Ekwealor and \\ Sampson C. Nwabuko
}

\author{
Department of Pharmaceutical and Medicinal Chemistry, University of Nigeria, Nsukka, 410001, \\ Enugu State, Nigeria
}

(Received: October 30, 2017; Accepted: December 05, 2017; Published (web): December 23, 2017)

\begin{abstract}
The present study was aimed at a comparative study of the phytoconstituents, antioxidant and antimicrobial properties of four medicinal plants, Ficus capensis, Aristolochia ringens, Albizia zygia and Lannea welwitschii. The leaf of $F$. capensis and stem bark of A. ringens, A. zygia and L. welwitschii were extracted using methanol. Phytochemical analysis was done spectrophotometrically. Three in vitro antioxidant tests-hydrogen peroxide $\left(\mathrm{H}_{2} \mathrm{O}_{2}\right)$, nitric oxide (NO) and 2, 2-diphenyl-1-picrylhydroxyl (DPPH) scavenging models were employed. Antimicrobial test was done by agar diffusion method against E. coli, Staphylococcus aureus, Klebsiela pneumonia, Bacillus subtilis, Pseudomonas aeruginosa, Salmonella typhi, Candida albicans and Aspergittus spp. Phytochemical analysis revealed that the most abundant phytoconstituents were flavonoids ( $F$. capensis and A. zygia), reducing sugar, terpenoids, alkaloids and tannins. In the antioxidant models, $A$. zygia was found to produce the least $\mathrm{IC}_{50}$ in two of the models (NO and DPPH). Results of the antimicrobial tests showed that A. zygia showed a broader spectrum of activity than other plants. This study has shown that these plants possess antioxidant and antimicrobial activities which further justify their usage in traditional medicines. A. zygia featured prominently in these activities. Also flavonoids could be responsible for the bioactivities of these plants.
\end{abstract}

Key words: Antioxidant, Aristolochia ringens, Albizia zygia, comparative phytochemical study, Ficus capensis, Lannea welwitschii.

\section{INTRODUCTION}

Several medicinal plants are used by many ethnic groups for the treatment of various ailments including dysentery, asthma, malaria skin diseases and a number of other indications. ${ }^{1}$ It is estimated that about $80 \%$ of the population worldwide use traditional medicine, which has compounds derived from medicinal plants. ${ }^{2}$ In addition, medicinal plants are known to be good sources of various bioactive compounds having various activities such as antioxidant and antimicrobial effects. Oxidative stress results from an imbalance between free radical species and the anti-oxidative system. High concentration of free radicals during oxidative stress

Correspondence to: Philip F. Uzor

E-mail:philip.uzor@unn.edu.ng

$+2348037008294$

Dhaka Univ. J. Pharm. Sci. 16(2): 147-157, 2017 (December) causes a loss of cellular function and mutagenesis and induces structural changes in cellular biomolecules, such as lipids, proteins and DNA. ${ }^{3,4}$ These alterations lead to the development and progression of chronic diseases, such as metabolic, neurological, pulmonary and cardiovascular diseases as well as cancer. ${ }^{3,5-7}$

In addition to the constituents with antioxidant activity, antimicrobial phytoconstituents are of interest because of problems of antibiotic resistance associated with the existing drugs. ${ }^{8-10}$ In addition, there are concerns about the safety status of the synthetic preservatives such as parabens, butylated hydroxytoluene (BHT) and butylated hydroxanisole (BHA). ${ }^{11}$ Several phytoconstituents are reported to possess inhibitory activities against some pathogenic microorganisms. ${ }^{12-14}$ 
Ficus capensis Thumb (family: Moraceae) Akakoro (Igbo, Nigeria) is an evergreen tree which is widely distributed in the tropics. The leaves and roots of the plant are traditionally used for the treatment of leprosy, tuberculosis, sexually transmitted diseases, convulsions, wounds, diarrhea and dysentery. ${ }^{15-19}$ The phytochemical screening, antioxidant and antimicrobial properties of the leaf extracts have been reported. ${ }^{20,21}$ In another study, the phytochemical screening and microbial inhibitory activities of the leaf, stem and bark of $F$. capensis were also investigated ${ }^{22}$. Earlier chemical studies on F. capensis resulted in the isolation of flavonols, sterols, triterpenes and coumarins from the leaf of the plant. ${ }^{23}$

Aristolochia ringens Vahl. is a perennial plant in the Aristolochiaceae family. In the south-western Nigeria (Yoruba), the plant is commonly known as 'Akogun'. It is an aromatic liane, scrambler, a climbing shrub or rhizome. The plant contains alkaloids and aristolochic acids. ${ }^{24,25}$ The plant is used locally in the treatment of wounds, dysentery, throat infections and skin problems. ${ }^{26}$ The antimicrobial potential and phytochemical composition of $A$. ringens root and bark have been investigated. ${ }^{26}$ In addition, the antidiabetic, ${ }^{27}$ antitrypanosomal ${ }^{24}$ and anticancer ${ }^{28}$ activities of the plant have been reported.

Albizia zygia (DC.) J. F. Macbr (family: Fabaceae) is commonly known as Atanza (Ngwu in Igbo, Nigeria). It is deciduous tree with a deciduous crown. ${ }^{29}$ The plant is used in the treatment of allergycaused respiratory disorders ${ }^{30}$ and diabetes ${ }^{31}$ and a variety of other conditions in Africa such as cough, fever, worms and female infertility. ${ }^{32,33}$ The antiprotozoal $^{30}$ and antimicrobial ${ }^{34}$ activities of the plant have been reported. In addition, the phytochemical, antioxidant, antimicrobial and toxicity activities of A. zygia stem-bark were investigated by Oloyede and Ogunlade. ${ }^{35}$

Lannea welwitschii (Hiern) Engl. (family: Anacardiaceae) is a deciduous or evergreen tree with a large, spreading crown which is found growing in forests of Africa. L. welwitschii is used for the treatment of swellings, oedema, hemorrhoids, gout, diarrhea, dysentery, gingivitis, topical infections, wounds, food poisoning, nasopharyngeal infections and emesis in traditional medicines. ${ }^{36,37}$ Phytochemical analysis has revealed the presence of glycosides, tannins, and saponins in the stem bark of the plant. ${ }^{36,38}$ Similarly, lanneaquinol and 2'-(R)hydroxylanneaquinol, two cytotoxic compounds, have been isolated from the plant. $^{39}$ The antidiarrheal, ${ }^{40}$ anti-allergic, anti-inflammatory, analgesic ${ }^{41}$ as well as antimicrobial and wound healing ${ }^{42,43}$ potentials of the plant have been reported.

Despite various biological investigations already done on the above plants, their phytochemical constituents and biological activities have not been compared. The present study was therefore aimed at comparing the phytochemical constituents, the antioxidant and antimicrobial properties of the plants in a bid to determine the most effective plant for the treatment of microbial infections and other diseases.

\section{MATERIALS AND METHODS}

Plant materials. The leaves of Ficus capensis and Aristolochia ringens as well as the stem barks of Albizia zygia (PC) J.F. Macbr. (Fabaceae) and Lannea welwitchi (Hern) Engl. (Anacardiaceae) were collected at Nsukka, Enugu State in June, 2016. They were authenticated by Mr. Felix Nwafor, a taxonomist with the Department of Pharmacognosy and Environmental Medicines, University of Nigeria, Nsukka. The voucher specimens (voucher number: PxUNN/021, PxUNN/022, PxUNN/024 and PxUNN/023 respectively) were deposited in the herbarium of the Department of Pharmacognosy and Environmental Medicines, University of Nigeria, Nsukka for future reference.

Preparation of plant extracts. The air-dried leaves of $F$. capensis and the stem barks of $A$. ringens, A. zygia and L. welwitchii were pulverized separately and the powdered materials (600 g each) were macerated with methanol by cold maceration for $72 \mathrm{~h}$ with intermittent agitation. They were filtered with a filter paper and the filtrates were concentrated with the aid of a rotary evaporator to afford the respective dry extracts. 
Phytochemical analysis of plant extracts. The methods of phytochemical analyses followed standard protocols as adopted ${ }^{44,45}$ with some modifications.

Determination of tannins. Each of the extracts $(0.1 \mathrm{~g}$ each) was dissolved with $50 \mathrm{ml}$ of distilled water. To $5 \mathrm{ml}$ of the filtrate, $0.3 \mathrm{ml}$ of $0.01 \mathrm{~N} \mathrm{FeCl}_{3}$ in $0.1 \mathrm{~N} \mathrm{HCl}$ was added. To the resultant solution, $0.3 \mathrm{ml}$ of $0.008 \mathrm{M}$ potassium ferricyanide was added and the mixture shaken. The absorbance was taken at $720 \mathrm{~nm}$. Tannin concentration was calculated from the calibration curve of tannic acid used as standard and results expressed as $\mathrm{g} / 100 \mathrm{~g}$ equivalent of tannic acid.

Determination of alkaloids. Each of the extracts $(0.5 \mathrm{~g}$ each) was titrated with $20 \mathrm{ml}$ of $20 \%$ $\mathrm{H}_{2} \mathrm{SO}_{4}$ ethanol (1:1) for $5 \mathrm{~min}$ and filtered. To $1 \mathrm{ml}$ of the filtrate, $5 \mathrm{ml}$ of $60 \% \mathrm{H}_{2} \mathrm{SO}_{4}$ was added and the solution was allowed to stand for $5 \mathrm{~min}$. To the solution, $5 \mathrm{ml}$ of $0.5 \%$ formaldehyde in $60 \% \mathrm{H}_{2} \mathrm{SO}_{4}$ was added and the solution mixed and stirred for 3 min. The absorbance was taken at $565 \mathrm{~nm}$. The alkaloid concentration was calculated from the calibration curve of atropine used as standard and results expressed as $\mathrm{g} / 100 \mathrm{~g}$ equivalent of atropine.

Determination of glycosides. Each of the extracts $(0.5 \mathrm{~g})$ was macerated with $20 \mathrm{ml}$ of distilled water. To the solution, $2.5 \mathrm{ml}$ of $15 \%$ lead acetate was added, followed by filtration. The filtrate was added $2.5 \mathrm{ml}$ of chloroform and mixed. The lower portion of the mixture was collected and evaporated to dryness. The residue gotten after dryness was dissolved with $3 \mathrm{ml}$ of glacial acetic acid and $0.1 \mathrm{ml}$ of $5 \%$ ferric chloride and $0.25 \mathrm{ml}$ of conc. $\mathrm{H}_{2} \mathrm{SO}_{4}$ were also added. The mixture was kept in a dark for 2 $\mathrm{h}$ and absorbance taken at $490 \mathrm{~nm}$. The concentration of glycosides was calculated from the calibration curve of n-octyl glycoside used as standard and results expressed as $\mathrm{g} / 100 \mathrm{~g}$ equivalent of the standard glycoside.

Determination of flavonoids. Each of the extracts $(0.1 \mathrm{~g}$ each $)$ was macerated with $10 \mathrm{ml}$ of ethylacetate and filtered. To $5 \mathrm{ml}$ of the filtrate, $5 \mathrm{ml}$ of dilute ammonia $\left(33.5 \mathrm{ml} / 100 \mathrm{ml}\right.$ of $\left.\mathrm{H}_{2} \mathrm{O}\right)$ was added. The upper layer was collected and absorbance measured of $490 \mathrm{~nm}$. The flavonoid concentration was calculated from the calibration graph of quercetin used as standard and results expressed as $\mathrm{g} / 100 \mathrm{~g}$ equivalent of quercetin.

Determination of saponin. Each of the extracts $(0.5 \mathrm{~g}$ each) was weighed out and $10 \mathrm{ml}$ of petroleum ether added and the mixture filtered. The residue was dried and dissolved with $6 \mathrm{ml}$ of methanol. Exactly 2 $\mathrm{ml}$ of the solution above was transferred into a test tube and $2 \mathrm{ml}$ of methanol was also added and finally $2 \mathrm{ml}$ of colour reagent (prepared from iron chloride solution and of conc. $\mathrm{H}_{2} \mathrm{SO}_{4}(1: 5)$ ). The mixture was allowed to stand for $30 \mathrm{~min}$ and absorbance taken at $550 \mathrm{~nm}$. The saponin concentration was calculated from the calibration graph of diosgenin used as standard and results expressed as $\mathrm{g} / 100 \mathrm{~g}$ equivalent of diosgenin.

Determination of terpenoids. Each of the extracts $(0.1 \mathrm{~g}$ each) was macerated with $20 \mathrm{ml}$ of absolute methanol and then filtered. To $1 \mathrm{ml}$ of the filtrate, $1 \mathrm{ml}$ of $5 \%$ phosphomolybdic acid and $1 \mathrm{ml}$ of conc. $\mathrm{H}_{2} \mathrm{SO}_{4}$ were added gently. The mixture was allowed to stand for $30 \mathrm{~min}$, then $2 \mathrm{ml}$ of methanol was added and the absorbance taken at $700 \mathrm{~nm}$. The concentration of terpenoids was calculated from the calibration curve of linolol used as standard and results expressed as $\mathrm{g} / 100 \mathrm{~g}$ equivalent of linolol.

Determination of steroids. $0.5 \mathrm{~g}$ of the dried extract was macerated with $20 \mathrm{ml}$ of methanol and then filtered. To the mixture and methanol blank $2 \mathrm{ml}$ of colour reagent (prepared from iron chloride solution and of conc. $\left.\mathrm{H}_{2} \mathrm{SO}_{4}(1: 5)\right)$ was added and absorbance taken at $550 \mathrm{~nm}$. The concentration of steroids was calculated from the calibration curve of cholesterol used as standard and results expressed as $\mathrm{g} / 100 \mathrm{~g}$ equivalent of cholesterol.

In vitro antioxidant assays of the extracts. Three in vitro antioxidant models were used to analyze the extracts. These include hydrogen peroxide scavenging $\left(\mathrm{H}_{2} \mathrm{O}_{2}\right), \quad 2, \quad$ 2-diphenyl-1picrylhydrozyl (DPPH) and nitric oxide (NO) scavenging assay models. 
Hydrogen peroxide scavenging $\left(\mathrm{H}_{2} \mathrm{O}_{2}\right)$ assay. The ability of the various extracts to scavenge $\mathrm{H}_{2} \mathrm{O}_{2}$ was estimated using the method of Ruch et al. ${ }^{46}$ Different concentrations $(20-100 \mathrm{mg} / \mathrm{ml})$ of the each of the extracts as well as ascorbic acid were prepared. To $5 \mathrm{ml}$ of each of the concentration of the samples, $40 \mathrm{mM}$ of $\mathrm{H}_{2} \mathrm{O}_{2}$ was added and absorbance taken at $230 \mathrm{~nm}$ after allowing the solution to stand for 10 min. Methanol was used as the blank (control). The absorbance was taken in replicate values. The percentage scavenging activity of $\mathrm{H}_{2} \mathrm{O}_{2}$ was calculated as (Eq. 1):

$\%$ scavenged $\left(\mathrm{H}_{2} \mathrm{O}_{2}\right)=\frac{A c-A t}{A s} X 100 \% \quad$ Eq. 1

where Ac $=$ absorbance of control, At $=$ absorbance of test.

Nitric oxide (NO) scavenging assay. Different concentrations $(0.2,0.3,0.4,0.5$ and $0.6 \mathrm{mg} / \mathrm{ml})$ of each of the extracts and ascorbic acid (positive control) were prepared. To each of the concentration, $0.5 \mathrm{ml}$ was pippeted out and $2 \mathrm{ml}$ of $10 \mathrm{mM}$ sodium nitroprusside was added and the mixture incubated for $180 \mathrm{~min}$ at $25^{\circ} \mathrm{C}$. From the incubated test tubes, $0.5 \mathrm{ml}$ was transferred into fresh test tubes and $0.5 \mathrm{ml}$ of Griess reagent added. These were allowed to stand for $30 \mathrm{~min}$. The procedure was repeated for the control using methanol. The absorbance was taken at $546 \mathrm{~nm} .{ }^{47}$ The $\%$ inhibition was calculated using Eq. 1.

DPPH model. Different concentrations (20 -100 $\mu \mathrm{g} / \mathrm{ml}$ ) of each of the extracts and ascorbic acid were prepared. To $1 \mathrm{ml}$ of each concentration prepared and $1 \mathrm{ml}$ of methanol as the negative control, $3 \mathrm{ml}(0.04$ $\mathrm{mM}$ ) of DPPH was added and the mixture allowed to stand for $30 \mathrm{~min}$ at room temperature in the dark. Then, the absorbance was taken at $517 \mathrm{~nm} .{ }^{48}$ The $\%$ inhibition was calculated using Eq. 1.

Antimicrobial assay. The antimicrobial study was carried out on the extracts using Muller Hinton agar for the bacteria and potato dextrose agar for the fungi. The organisms used were: E. coli, Staphylococus aureus, Klebsiella pneumonia, B. subtilis, Pseudomonas aeruginosa, Salmonella typhi, Candida albicans and Aspergittus spp. Laboratory strains of the micro-organisms were used for the study.

Preparation of nutrient agar. Muller-Hinton agar typically contains $2.9 \mathrm{~g}$ beef extract, $17.5 \mathrm{~g}$ casein hydrolysate, $1.5 \mathrm{~g}$ starch and $17.0 \mathrm{~g}$ agar dissolved in 1 liter of distilled water. It was prepared by suspending $38 \mathrm{~g}$ of the medium in 1 liter of distilled water. This was boiled for $1 \mathrm{~min}$ and autoclaved at $121{ }^{\circ} \mathrm{C}$ for $15 \mathrm{~min}$. It was finally poured into sterile Petri dishes. Potato dextrose agar was prepared by mixing the potato infusion with dextrose, agar and water and boiled to dissolve. It was also autoclaved at $121^{\circ} \mathrm{C}$ for $15 \mathrm{~min}$.

Preparation of culture. The culture is prepared by method of clinical isolation of the organisms with antimicrobial resistant properties.

Procedure for antimicrobial test. The experiment was done on the extracts using agar diffusion method. Different concentrations (6.25, $12.5,25,50$ and $100 \mathrm{mg} / \mathrm{ml}$ ) of each of the samples were prepared using two fold serial dilutions. Each of the respective agar medium was seeded with the corresponding microorganism and allowed to gel. To the cooled agar, cock borer was used to bore holes for each of the different concentrations prepared. About 8 drops each of the different concentrations were transferred to the respective holes bore and the antimicrobial standard disc of oxacillin $5 \mu \mathrm{g}$ was used as the standard. The plates were incubated for $24 \mathrm{~h}$ at $37^{\circ} \mathrm{C}$ and the zone of inhibition (IZD) was measured. The MIC was determined by plotting the graph of IZD ${ }^{2}$ against logarithm of concentration and taking the anti-log of the intercept on $\mathrm{X}$ - axis.

Statistical analysis. Measurements were determined in triplicates and results analyzed statistically (SPSS version 21) by One-way analysis of variance (ANOVA) followed by Turkey post hoc test. Data are presented as mean \pm SEM; $p<0.05$ was considered significant.

\section{RESULTS AND DISCUSSION}

Phytochemicals results. Results of quantitative phytoconstituents of the four plants (Table 1) showed that $L$. welwitchii has the largest amount of alkaloid 
$(2.77 \pm 0.01 \mathrm{~g} / 100 \mathrm{~g})$, followed by A. zygia and $F$. capensis while $A$. ringens has the least alkaloid. The flavonoid contents of the plants were found in the order: $F$. capensis > A. zygia >A. ringens $>L$. welwitchii. The flavonoid contents of $A$. ringens and A. zygia are not significantly ( $p>0.05)$ different but they differ from the other plants in this regard. Steroids and terpenoids were relatively most abundant in A. ringens $(0.56 \pm 0.19$ and $2.08 \pm 0.00$ $\mathrm{g} / 100 \mathrm{~g}$ respectively) and they were observed in this order: A. ringens $>F$. capensis $>$ A. zygia $>L$. welwitchii. However, statistically, all the plants have similar ( $p>0.05)$ contents of steroids. All the plants have relatively large amounts of reducing sugars $(3.46-11.67 \mathrm{~g} / 100 \mathrm{~g})$ but a little quantity of glycosides (0.05-0.17 g/100g). Saponins were present in negligible amounts in $F$. capensis and A. ringens but were moderately present in A. zygia $(0.11 \pm 0.02$ $\mathrm{g} / 100 \mathrm{~g})$ and $L$. welwitchii $(0.10 \pm 0.00 \mathrm{~g} / 100 \mathrm{~g})$. The saponin contents of A. zygia $(0.11 \pm 0.02 \mathrm{~g} / 100 \mathrm{~g})$ and $L$. welwitchii $(0.10 \pm 0.00 \mathrm{~g} / 100 \mathrm{~g})$ are similar (p> $0.05)$ and relatively higher than those of $F$. capensis $(0.003 \pm 0.00 \mathrm{~g} / 100 \mathrm{~g})$ and $A$. ringens $(0.003 \pm 0.00$ $\mathrm{g} / 100 \mathrm{~g})$ which also showed similar $(\mathrm{p}>0.05)$ contents. Tannins were moderately present in all the plants but were found to be most abundant in $L$. welwitchii and in F. capensis. In all the plants, the most abundant phytoconstituents were the flavonoids, sugars, terpenoids, alkaloids and tannins.

Table 1. Phytochemical constituents of the plants.

\begin{tabular}{|c|c|c|c|c|}
\hline \multirow[t]{2}{*}{ Phytochemical } & \multicolumn{4}{|c|}{ Concentration $(\mathrm{g} / 100 \mathrm{~g})$} \\
\hline & F. capensis & A. ringens & A. zygia & L. welwitchii \\
\hline Alkaloids & $0.93 \pm 0.01^{\mathrm{a}}$ & $0.85 \pm 0.01^{\mathrm{b}}$ & $1.13 \pm 0.01^{\mathrm{c}}$ & $2.77 \pm 0.01^{\mathrm{d}}$ \\
\hline Flavonoids & $4.06 \pm 0.01^{\mathrm{a}}$ & $2.85 \pm 0.00^{\mathrm{b}}$ & $3.28 \pm 0.00^{\mathrm{b}}$ & $2.04 \pm 0.32^{\mathrm{c}}$ \\
\hline Glycosides & $0.16 \pm 0.00^{\mathrm{a}}$ & $0.17 \pm 0.00^{\mathrm{b}}$ & $0.05 \pm 0.00^{\mathrm{c}}$ & $0.10 \pm 0.00^{\mathrm{d}}$ \\
\hline Reducing sugars & $9.12 \pm 0.04^{\mathrm{a}}$ & $3.46 \pm 0.03^{\mathrm{b}}$ & $4.94 \pm 0.02^{\mathrm{c}}$ & $11.67 \pm 0.03^{\mathrm{d}}$ \\
\hline Saponins & $0.003 \pm 0.00^{\mathrm{a}}$ & $0.004 \pm 0.00^{\mathrm{a}}$ & $0.11 \pm 0.02^{\mathrm{b}}$ & $0.10 \pm 0.00^{\mathrm{b}}$ \\
\hline Steroids & $0.27 \pm 0.00^{\mathrm{a}}$ & $0.56 \pm 0.19^{\mathrm{a}}$ & $0.18 \pm 0.00^{\mathrm{a}}$ & $0.14 \pm 0.00^{\mathrm{a}}$ \\
\hline Tannins & $1.63 \pm 0.01^{\mathrm{a}}$ & $0.48 \pm 0.02^{\mathrm{b}}$ & $0.59 \pm 0.01^{\mathrm{c}}$ & $1.77 \pm 0.01^{\mathrm{d}}$ \\
\hline Terpenoids & $1.37 \pm 0.00^{\mathrm{a}}$ & $2.08 \pm 0.00^{\mathrm{b}}$ & $1.34 \pm 0.00^{\mathrm{c}}$ & $1.23 \pm 0.00^{\mathrm{d}}$ \\
\hline
\end{tabular}

Different superscripts $(\mathrm{a}-\mathrm{d})$ on the same row indicate significantly different $(\mathrm{p}<0.05)$ mean.

\section{Antioxidant results}

Hydrogen peroxide model. Figure 1 shows the results of the inhibition of $\mathrm{H}_{2} \mathrm{O}_{2}$ by the various plants. Increasing concentration of the extracts of all the plants produced corresponding increase in the $\%$ inhibition of $\mathrm{H}_{2} \mathrm{O}_{2}$. However, $A$. ringens had the least steep slope. The $\mathrm{IC}_{50}$ values (Table 2) shows that $A$. ringens has the least $\mathrm{IC}_{50}(45.45 \pm 0.08 \mu \mathrm{g} / \mathrm{ml})$ in the $\mathrm{H}_{2} \mathrm{O}_{2}$ model followed by A. zygia $(50.08 \pm 0.03$ $\mu \mathrm{g} / \mathrm{ml})$. All the plants have lower $\mathrm{IC}_{50}$ than ascorbic acid $(153.47 \pm 0.46 \mu \mathrm{g} / \mathrm{ml})$ in the $\mathrm{H}_{2} \mathrm{O}_{2}$ model. The inhibitory effects of the four plants against $\mathrm{H}_{2} \mathrm{O}_{2}$ are statistically not different $(p>0.05)$.

NO inhibition model. In the NO inhibition antioxidant model, all the plant extracts produced concentration related inhibition of NO (Figure 2). However, A. zygia produced the least $\mathrm{IC}_{50}(13.18 \pm$ $0.14 \mu \mathrm{g} / \mathrm{ml})$; the order is as follows: A. zygia $<L$. welwitchii $<F$. capensis $<$ ascorbic acid $<A$. ringens (Table 2). F. capensis and ascorbic acid produced similar ( $\mathrm{p}>0.05$ ) inhibitory effect against NO.

DPPH model. Figure 3 shows that all the plant extracts exhibited concentration related inhibition of DPPH while table 2 shows that the plant with the least $\mathrm{IC}_{50}$ in the DPPH model was A. zygia $(10.00 \pm 0.02 \mu \mathrm{g} / \mathrm{ml})$. As observed in NO model above, F. capensis and ascorbic acid produced similar ( $\mathrm{p}>0.05$ ) inhibitory effect against DPPH. Also A. ringens and ascorbic acid produced similar ( $\mathrm{p}$ $>0.05$ ) effect against DPPH. 
In all the three antioxidant models (Table 2), A. zygia was found to produce the least $\mathrm{IC}_{50}$ in two of the models (NO and DPPH). This was followed by $A$. ringens, $L$. welwitchii and $F$. capensis. Most of the plant extracts produced lower $\mathrm{IC}_{50}$ in all the three models than ascorbic acid.

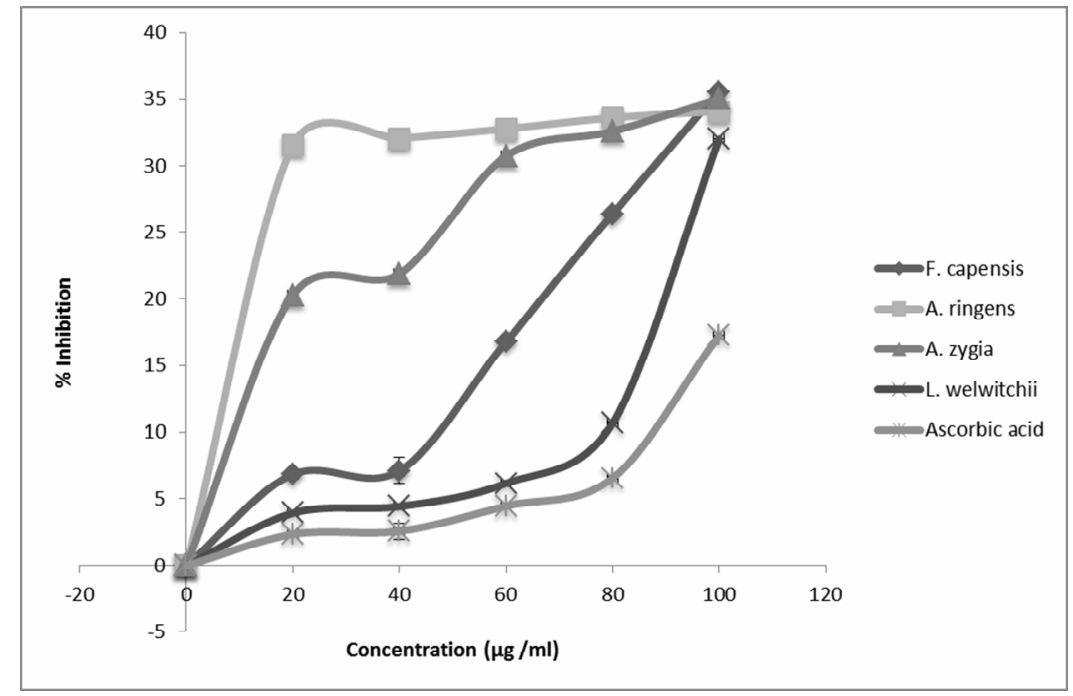

Figure 1. Inhibition of $\mathrm{H}_{2} \mathrm{O}_{2}$ by $F$. carpensis, A. ringens, A. zygia, L. welwitchii and ascorbic acid.

Table 2. The $\mathrm{IC}_{50}$ from the antioxidant studies of the plant extracts and ascorbic acid.

\begin{tabular}{lccc}
\hline Test sample & \multicolumn{1}{c}{$\mathrm{IC}_{50}$} & DPPH model $(\mu \mathrm{g} / \mathrm{ml})$ \\
\cline { 2 - 4 } & $\mathrm{H}_{2} \mathrm{O}_{2}$ model $(\mu \mathrm{g} / \mathrm{ml})$ & NO model $(\mu \mathrm{g} / \mathrm{ml})$ & $36.92 \pm 0.15^{\mathrm{a}}$ \\
\hline F. capensis & $75.91 \pm 0.03^{\mathrm{a}}$ & $26.46 \pm 0.48^{\mathrm{a}}$ & $33.96 \pm 1.14^{\mathrm{b}}$ \\
A. ringens & $45.45 \pm 0.08^{\mathrm{b}}$ & $34.24 \pm 0.10^{\mathrm{b}}$ & $10.00 \pm 0.02^{\mathrm{c}}$ \\
A. zygia & $50.08 \pm 0.03^{\mathrm{c}}$ & $13.18 \pm 0.14^{\mathrm{c}}$ & $72.55 \pm 0.07^{\mathrm{d}}$ \\
L. welwitchii $_{\text {Ascorbic acid }}$ & $95.56 \pm 0.12^{\mathrm{d}}$ & $16.01 \pm 0.02^{\mathrm{d}}$ & $35.24 \pm 0.62^{\mathrm{ab}}$ \\
\hline
\end{tabular}

Different superscripts $(\mathrm{a}-\mathrm{e})$ on the same column indicate significantly different $(\mathrm{p}<0.05)$ mean.

Table 3. Result of the preliminary antimicrobial screening.

\begin{tabular}{lcccc}
\hline Organism & \multicolumn{3}{c}{ Plant extract } \\
\cline { 2 - 4 } & F. capensis & A. ringen & A. zygia & L. welwitchii \\
\hline Gram positive bacteria & & & & + \\
\hline B subtilis & + & + & + & - \\
S. aureus & - & - & - & - \\
\hline Gram negative bacteria & & & & - \\
\hline E. coli & - & - & + & - \\
K. pneumonia & - & - & + & - \\
P. aeruginosa & - & + & + & - \\
S. typhi & - & - & & - \\
\hline Fungi & - & & + & + \\
\hline Aspergillus $s p p$ & - albicans & - & + & \\
\hline
\end{tabular}


Table 4. Antimicrobial activities of the plant extracts.

\begin{tabular}{|c|c|c|c|c|c|c|c|}
\hline \multirow{3}{*}{ Organism } & \multirow{3}{*}{ Organism } & \multicolumn{5}{|c|}{ Concentration $(\mathrm{mg} / \mathrm{ml})$} & \multirow{3}{*}{$\begin{array}{c}\mathrm{MIC} \\
(\mathrm{mg} / \mathrm{ml})\end{array}$} \\
\hline & & 100 & 50 & 25 & 12.5 & 6.251 & \\
\hline & & \multicolumn{5}{|c|}{ IZD (mm) } & \\
\hline \multirow[t]{4}{*}{ B. subtilis } & F. capensis & 17 & 15 & 13 & 11 & 9 & 2.41 \\
\hline & A. ringens & 20 & 17 & 14 & 11 & 14 & 3.73 \\
\hline & A. zygia & 21 & 18 & 14 & 12 & 9 & 3.40 \\
\hline & L. welwitchii & 17 & 14 & 12 & 11 & 10 & 3.1 \\
\hline E. coli & A. zygia & 22 & 19 & 16 & 15 & 13 & 2.10 \\
\hline \multirow[t]{2}{*}{ P. aeruginosa } & A. ringens & 11 & 12 & 13 & 15 & 16 & 0.74 \\
\hline & A. zygia & 17 & 14 & 12 & 11 & 10 & 3.10 \\
\hline S. typhi & A. zygia & 23 & 19 & 16 & 14 & 12 & 2.50 \\
\hline Aspergillus spp & A. zygia & 18 & 16 & 14 & 12 & 9 & 3.40 \\
\hline \multirow[t]{2}{*}{ C. albicans } & A. ringens & 8 & 10 & 11 & 13 & 14 & 1.72 \\
\hline & A. zygia & - & - & 11 & 12 & 14 & 1.80 \\
\hline
\end{tabular}

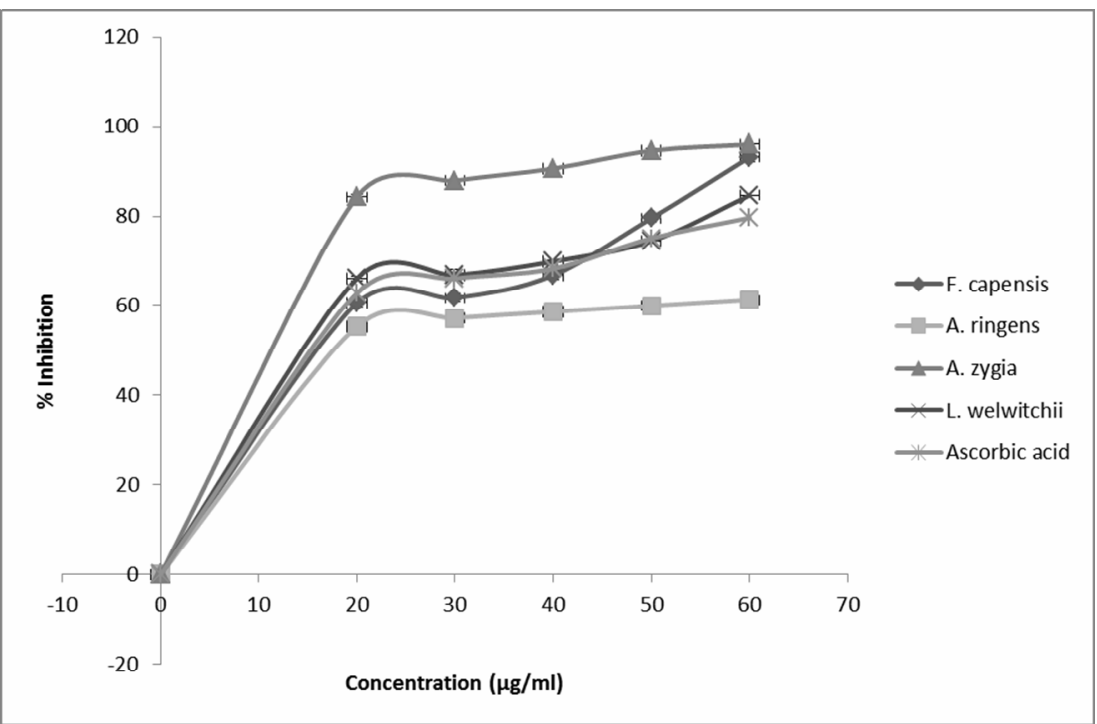

Figure 2. Inhibition of NO by F. carpensis, A. ringens, A. zygia, L. welwitchii and ascorbic acid.

Results of antimicrobial testing. The results of the antimicrobial testing (Tables 3 and 4) showed that only one of the Gram positive bacteria (B. subtilis) was sensitive to the plant extracts with the MIC in the order: F. capensis $<$ L. welwitchii $<$ A. zygia $<A$. ringens. Also $S$. aureus was not sensitive to any of the plant extracts. Among the Gram negative bacteria, only $K$. pneumonia was not sensitive to any of the plants. E. coli was sensitive to only A. ringens (MIC $=2.10 \mathrm{mg} / \mathrm{ml}$ ) while $S$. typhi was sensitive to only A. zygia ( $\mathrm{MIC}=2.50 \mathrm{mg} / \mathrm{ml}$ ). $P$. aeruginosa was sensitive to A. ringens and A. zygia with MIC of
A. zygia $(0.74 \mathrm{mg} / \mathrm{ml})$ lower than that of $A$. ringens ( $3.10 \mathrm{mg} / \mathrm{ml}$ ). The mould, Aspergillus spp was only sensitive to A. zygia with MIC of $3.40 \mathrm{mg} / \mathrm{ml}$ while C. albicans was sensitive to A. ringens and A. zygia with MIC of 1.72 and $1.80 \mathrm{mg} / \mathrm{ml}$ respectively. Overall, A. ringens exhibited the least MIC (against $P$. aeruginosa). Also A. ringens and A. zygia were found to be more effective against most of the organisms tested but A. zygia showed a broader spectrum of activity (A. zygia was effective against six organisms while $A$. ringens was effective against 
three organisms). F. capensis and L.welwitchii were only active against $B$. subtilis.

In the present study, we have compared the abundance of flavonoids, reducing sugars, terpenoids, alkaloids and tannins in the various plants. The presence of varying amounts of flavonoids, terpenes and steroids in the leaf extracts of $F$. capensis have been reported using GC, HPLC and UVspectrophotemetric methods ${ }^{20}$ while the present study employed UV-spectrophotemetric method to establish the presence of these phytochemicals. Also the root and stem bark of A. rigens were found to contain flavonoids, alkaloids, tannins, cardiac glycosides and steroids in a previous study, though these phytochemicals were not quantified and there were absent of saponins and steroids in the stem bark. $^{26}$

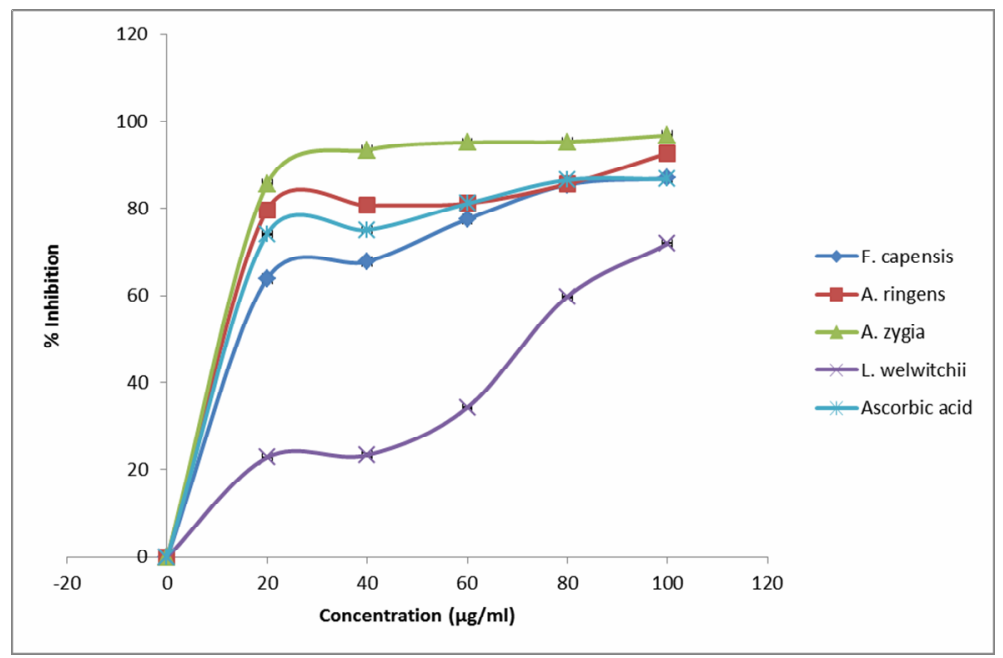

Figure 3. Inhibition of DPPH by F. carpensis, A. ringens, A. zygia, L. welwitchii and ascorbic acid.

Similarly, the presence of these phytochemicals was detected in the hexane and methanol extracts of A. zygia stem bark, though tannins and flavonoids were absent in the methanol extract ${ }^{35}$. Anthocyanosides and cyanogenic glycosides were also found to be absent in the leaf of A. zygia. ${ }^{34}$ Flavonoids, one of the the most abundant phytochemicals in the plants, are known to have a wide array of therapeutic activities such as antihypertensive, anti-rheumatism, antimicrobial, diuretic and antioxidant effects. ${ }^{32,45}$ It is suggested that the biological activities of these plants could be due to the presence of flavonoids or the other phytochemicals.

The antioxidant activity of the four medicinal plants was investigated by three in vitro models and the plants showed varying degrees of antioxidant activity (and varying $\mathrm{IC}_{50}$ ) by inhibiting the free radicals. Our data suggest that the $\mathrm{IC}_{50}$ against the free radicals were exhibited in this order: A. zygia $<$ A. ringens $<L$. welwitchii $<F$. capensis. This shows that A. zygia exhibits stronger antioxidant activity than the other three plants. In a previous report, which is in agreement with the present findings, A. zygia hexane and methanol extracts exhibited better free radical scavenging activity in the DPPH and $\mathrm{H}_{2} \mathrm{O}_{2}$ models than the standard drugs, $\alpha$ tocopherol, butylated hydroxyanisole and ascorbic acid. ${ }^{35}$ Also $F$. capensis leaf extracts (essential oil, methanol-water and water) were shown to exhibit antioxidant activity in DPPH model with $\mathrm{IC}_{50}$ ranging from 10.25 to $23.34 \mu \mathrm{g} / \mathrm{ml}^{20}$ while the present study obtained a relatively higher $\mathrm{IC}_{50}(36.90 \pm 0.21 \mu \mathrm{g} / \mathrm{ml})$ from the leaf methanol extract of the plant. The leaf extract of $L$. welwitchii exhibits antioxidant in DPPH model with $\mathrm{IC}_{50}$ of $81.8 \mu \mathrm{g} / \mathrm{ml}^{37}$ similar to the stem 
bark extract used in the present study $\left(\mathrm{IC}_{50}=72.50 \pm\right.$ $0.23 \mu \mathrm{g} / \mathrm{ml})$.

Similar to the antioxidant activity, our data also shows that A. zygia exhibited a broader spectrum of antimicrobial activity than the other plants while $F$. capensis and $L$. welwitchii exhibited the least spectrum of activity against the organisms. Previous studies on the antimicrobial activities of A. zygia stem bark $^{35}$ and the leaf ${ }^{34}$ are in agreement with the present findings of strong antimicrobial activity of $A$. zygia. Also weak activity on some bacteria and fungi by the leaf extracts (essential oil, methanol-water and water of $F$. capensis) has been reported. ${ }^{20}$ However, the activity against some selected bacteria seemed to improve when the extract was extracted with ethanol or water. ${ }^{22}$ Methanol extract of $F$. capensis leaf showed activity only against gram-positive bacteria in the present study. Earlier workers have also shown that the stem and root bark of $A$. ringens exhibit broad antimicrobial activity against selected bacteria and fungi. ${ }^{26}$ This is in agreement with the present study which shows the broad antimicrobial activity of the leaf extract of $A$. ringens. The leaf extract of $L$. welwitchii exhibits broad antimicrobial activity against selected bacteria and fungi with MIC ranging from 2.5 to $10 \mathrm{mg} / \mathrm{ml} .{ }^{37}$ However, the present study showed that the stem bark exhibited antimicrobial activity against only $B$. subtilis with MIC of 3.1 $\mathrm{mg} / \mathrm{ml}$. Gram-negative bacteria cause infections, such as cholera, typhoid, meningitis and various kinds of gastrointestinal distresses. Secondary infections in hospitals are usually a result of infections by gramnegative bacteria. Fungi are also known to cause a number of diseases in the human body such as candidiasis, thrush, ringworm. The activity of these plant extracts, especially A. zygia and A. ringens, against these micro-organisms are indications of the presence of antimicrobial constituents in the plants.

\section{CONCLUSION}

The present study has shown that leaf of $F$. capensis as well as the stem bark of A. ringens, A. zygia and $L$. welwitchii possess antioxidant and antimicrobial properties. A. zygia featured prominently in these activities. The abundance of flavonoids, reducing sugars, terpenoids, alkaloids and tannins was observed in these plants and these phytochemicals could be responsible for the biological activities of the plants. The present study supports previous works on these plants and further justifies the traditional use of these plants in the treatment of various diseases. In the light of our current findings, A. zygia and A. ringens could be considered for future detailed isolation and evaluation of their bioactive constituents.

\section{REFERENCES}

1. Dahanukar, S.A., Kulkarni, R.A. and Rege, N.N. 2000. Pharmacology of medicinal plants and natural products, Ind. J. Pharm. 32, 81-118.

2. Manandhar, N.P. 2000. Plants and People of Nepal. Timber Press, USA, p. 50.

3. Hiransai, P., Tangpong, J., Kumbuar, C., Hoonheang, N. and Rodpech, O., et al. 2016. Anti-nitric oxide production, antiproliferation and antioxidant effects of the aqueous extract from Tithonia diversifolia, Asian Pac. J. Trop. Biomed. 6, 950-956.

4. Jones, D.P. and Sies, H. 2015. The redox code, Antioxid Redox Signal, 23, 734-746.

5. Go, Y.M. and Jones, D.P. 2011. Cysteine/cystine redox signaling in cardiovascular disease. Free Radic. Biol. Med. 50, 495-509.

6. Maehre, H.K., Jensen, I.J., Elvevoll, E.O. and Eilertsen, K.E. 2015. U-3 Fatty acids and cardiovascular diseases: effects, mechanisms and dietary relevance, Int. J. Mol. Sci. 16, 22636-22661.

7. Radi, R. 2013. Peroxynitrite, a stealthy biological oxidant. J. Biol. Chem. 288, 26464-26472.

8. Hemalatha, M., Thirumalai, T., Saranya, R., Elumalai, E.K. and David, E. 2013. A review on antimicrobial efficacy of some traditional medicinal plants in Tamilnadu. J. Acute Dis. 2, 99-105.

9. Mora, A., Blanco, J.E., Blanco, M., Alonso, M.P. and Dhabi, G. 2005. Antimicrobial resistance of Shiga toxin (verotoxin)producing Escherichia coli O157: H7 and non-O157 strains isolated from humans, cattle, sheep and food in Spain. Res. Microbiol, 156, 793 - 806.

10. Navon-Venezia, S., Ben-Ami, R. and Carmeli, Y. 2005. Update on Pseudomonas aeruginosa and Acinetobacter baumannii infections in the healthcare setting. Curr. Opin. Infect. Dis. 18, 306 - 313. 
11. Bergfeld, W.F., Belsito, D.V., Marks, J.G.J. and Andersen, F.A. 2005. Safety of ingredients used in cosmetics. J. Am. Acad. Dermatol. 52, 125 - 132.

12. Sandabe, U.K., Onyelili, P.A. and Chibuzo, G.A. 2006. Phytochemical screening and effects of aqueous extract of Ficus sycomorus L. (Moraceae) stem bark on muscular activity in laboratory animals. J. Ethnopharmacol. 104, 283285.

13. Solomon-Wisdom, G.O., Shittu, G.A. and Agboola, Y.A. 2011. Antimicrobial and phytochemical screening activities of Ficus Sur (Forssk), New York Sci. J. 4, 15-18.

14. Udobi, C.E., Onaolapo, J.A. and Agunu, A. 2008. Antibacterial activities and bioactive components of the aqueous fraction of the stem bark of Parkia bigblobosa (JACQ) (Mimosaceae). Nigerian J. Pharm. Sci. 7, 49-55.

15. Nguyi, A. 1988. Tannins of some Nigerian flora. $J$. Biotechnol. 6. 221-226.

16. Dafalla, H.A.A. 2005. Studies on constituents of Ficus capenis Thunb. Pak. J. Soc. Sci. 3, 751 - 754.

17. Irvine, F.R. 1961. Woody Plants of Ghana with Special Reference to their Uses. Oxford University Press, London, pp. 347-349.

18. Ahmadu, A.A., Zezi, A.U. and Yaro, A.H. 2007. Antidiarrheal activity of the leaf extracts of Daniella oliveri Hutch and Dalz (Fabceae) and Ficus sycomorus Miq (Moraceae), Afr. J. Trad. CAM. 4, 524-528.

19. Oyeleke, S.B., Dauda, B.E.N. and Boye, O.A. 2008. Antibacterial activity of Ficus capensis. Afr. J. Biotechnol. 7, $1414-1417$

20. Muanda, N.F., Dicko, A. and Soulimani, R. 2010. Chemical composition and biological activities of Ficus capensis leaves extracts. J. Nat. Prod. 3, 147-160.

21. Igwe, K.K., Udeh, N.E., Madubuike, A.J. and Amuneke, C.C. 2016. Characterization and antimicrobial studies of Ficus capensis methanolic leaf extract. Int. J. Adv. Res. Sci. Eng. Technol. 3, 1931-1940.

22. Adebayo-Tayo, B.C. and Odeniyi, A.O. 2012. Phytochemical screening and microbial inhibitory activities of Ficus Capensis. Afr. J. Biomed. Res. 15, 35- 40.

23. Abdalla, H. and Dafalla, A. 2005. Studies on the chemical constituents of Ficus capensis (Thunb), Pak. J. Soc. Sci. 3, 751-754.

24. Osho, I.B. and Lajide, L. 2014. Antitrypanosomal activity of Aristolochia ringens against Trypanosoma congolense infection in mice. J. Pharmacog. Phytother. 6, 1-3.

25. Mabberley, D.J. 1993. The Plant Book. Department of Plant Science, University of Oxford Press Syndicate of the University of Cambridge, p. 707.
26. Fasola, T.R., Oluwole, M.E., Obatayo, O. and Obayagbo, S.E. 2015. The antimicrobial potential and phytochemical composition of Aristolochia ringens Vahl. Adv. Life Sci. Technol. 29, 5-12.

27. Sulyman, A.O., Akolade, J.O., Sabiu, S.A., Aladodo, R.A. and Muritala, H.F. 2016. Antidiabetic potentials of ethanolic extract of Aristolochia ringens (Vahl.) roots. $J$ Ethnopharmacol. 182, 122-128.

28. Akindele, A.J., Wani, Z., Mahajan, G., Sharma, S. and Aigbe, F.R., et al. 2015. Anticancer activity of Aristolochia ringens Vahl. (Aristolochiaceae). J. Trad. Compl. Med. 5, $35-41$.

29. Petzke, K.J. 1997. Amino acid composition, available lysine content and in vitro protein digestibility of selected tropical crop seeds. Plant Food Human Nutr. 50, 151-162.

30. Ndjakou, L.B., Vonthron-Senecheau, C., Fongang, S.R., Tantangmo, F. and Ngouela, S., et al. 2007. In vitro antiprotozoal activities and cytotoxicity of some selected Cameroonian medicinal plants. J. Ethnopharmacol. 111, 8-12.

31. Mustafa, A., Fawibe, O., Ajiboye, A. and Agboola, D. 2014. Ethnobotanical survey of medicinal plants used in the treatment of diabetes in Irepodun Local Government Area of Osun State, Nigeria. Greener J. Bio. Sci. 4, 059-068.

32. Burkill, H.M. 1988. The useful plants of West Tropical Africa, 2nd Edition, Royal Botanical Garden, Kew, pp. 237238 .

33. Wezel, A. and Bender, S. 2003. Plants species diversity of home gardens of Cabu and its significance for household food supply. Agroforest. Syst. 57, 39-49.

34. Odeyemi, O., Oluduro, A.O. and David, O.M. 2014 Evaluation of antimicrobial activities of Albizia zygia DC leaf extracts against some clinically important pathogens. J. Nat. Sci. Res. 4, 98-105.

35. Oloyede, G.K. and Ogunlade, A.O. 2013. Phytochemical screening, antioxidant, antimicrobial and toxicity activities of polar and non-polar extracts of Albizia zygia (DC) stem-bark. Ann. Rev. Res. Biol. 3, 1020-1031.

36. Iwu, M.M. 1993. Handbook of African Medical Plants. CRC Press, Boca Raton, Fla, USA.

37. Agyare, C., Asase, A., Lechtenberg, M., Niehues, M. and Deters, A., et al. 2009. An ethnopharmacological survey and in vitro confirmation of ethnopharmacological use of medicinal plants used for wound healing in BosomtwiAtwima-Kwanwoma area, Ghana. J. Ethnopharmacol. 125, 393-403.

38. Baden, C., Balkwill, K., Getliffe, N.F.M., Immelman, K.L. and Manning, J.C. 1995. Acanthaceae-Justiciinae, vol. 30, Flora of Southern Africa, part 3, fascicle 1, National Botanical Institute, Pretoria, South Africa. 
39. Groweiss, A., Cardellina, J.H. II, Pannell, L.K., Uyakul, D. and Kashman, Y. 1997. Novel cytotoxic, alkylated hydroquinones from Lannea welwitschii. J. Nat. Prod. 60, 116-121.

40. Olatokunboh, A.O., Mofomosara, S.H. and Ekene, O.A. 2010. Evaluation of the antidiarrhoeal effect of Lannea welwitschii Hiern (Anacardiaceae) bark extract. Afr. J. Pharm. Pharmacol. 4, 165-169.

41. Obiri, D.D., Osafo, N., Dei-Anane, S., Adjei, R.K. and Ababio, E.O. 2013. Anti-allergic, anti-inflammatory and analgesic actions of stem bark extract of Lannea welwitschii (Anarcadiaceae) in mice, Int. J. Pharm. Pharm. Sci. 5, 217222.

42. Agyare, C., Bempah, S.B., Boakye, Y.D., Ayande, P.G. and Adarkwa-Yiadom, M. 2013. Evaluation of antimicrobial and wound healing potential of Justicia flava and Lannea welwitschii. Evidence-Based Compl. Altern. Med. Article ID 632927.
43. Deji-Agboola, A.M. and Olajubu, F.A. 2010. Antimicrobial activity of Lannea welwitschii stem bark against wound pathogens. Ethiop. Pharma. J. 28, 110-116.

44. Harborne, J.B. 1998. Phytochemical Methods, A guide to Modern Techniques of Plant analysis. 2nd ed., Chapman and Hall, London, pp. 54-84.

45. Trease, G.E. and Evans, W.E. 2002. Pharmacognosy, 15th ed., W.B. Saunders Company Limited, London, p. 585.

46. Ruch, R.J., Cheng, S.J. and Klaunig, J.E. 1989. Prevention of cytotoxicity and inhibition of intercellular communication by antioxidant catechins isolated from Chinese green tea. Carcinogen, 10, 1003-1008.

47. Green, L.C., Wagner, D.A., Glogowski, J., Skipper, P.L. and Wishnok, J.S. 1982. Analysis of nitrate, nitrite and $15 \mathrm{~N}$ nitrate in biological fluids. Anal. Biochem. 126, 131-138.

48. Tang, M.K., Ren, D., Zhang, J.T. and Du, G.H. 2002. Effect of salvianolic acids from Radix salviae miltiorrhizae on regional cerebral blood flow and platelet aggregation in rats. Phytomed. 9, 405- 409. 